\title{
Introduction: Special Issue on Choices and Challenges: Contemporary Families
}

\author{
Heather Laube, Special Issue Editor \\ University of Michigan-Flint
}

\begin{abstract}
The broad theme of this special issue of Michigan Family Review, "Choices and Challenges: Contemporary Families," was designed to reflect the diversity of contemporary family forms, the challenges families confront, and the contexts that shape the choices made by individuals and families. The range of articles in this issue reflects the diversity of families and the issues they confront.
\end{abstract}

The opening article focuses on a family form that is often ignored - singles and couples without children. Settle and Brumley find that the women they interviewed traverse different paths to their decision to be childfree, but share common explanations for their choice. They describe what they see as an impossibility high standard for "good" mothering, express their satisfaction with their lifestyles, and share an unwillingness to forego their independence. Changes in gendered expectations for women and men may mean that people who do choose to parent have a broader range of options than ever before. Contemporary ideals of fatherhood include expectations that men will take an active role in childrearing, and Solomon's research examines the experiences of men who choose to be stay-at-home fathers and finds they are developing a new definition of masculinity that reflects and supports their still fairly unique family roles. In "Feeding the Communal Family," Sullivan-Catlin examines how families in a cohousing community navigate the tension between the desire to reduce and redistribute the gendered household labor of meal planning and preparation and the cultural ideal of the "family meal" as a key aspect of close family time. These 
three articles provide insight into the challenges and benefits of "doing family differently."

The final two articles in this special issue focus on the intersections of gender, race, and social class. Bailey-Fakhoury examines how middle-class Black mothers in suburban white communities engage with schools and teachers as they work to develop positive racial identity in their daughters. Lindhorst Everhardt analyzes the experiences of women of color at another point on the social class spectrum in her study of barriers low income women confront as they attempt to achieve self-sufficiency. The women in Bailey-Fakhoury's study have achieved the American Dream of home ownership and are navigating the reality of their lives as women (and mothers) of color in white communities. Many of the low income women Lindhorst Everhardt interviews express a desire to own their own homes, but they confront both personal and structural obstacles that make this little more than a dream.

The shapes our families take, our roles within them, and the choices we see as viable, are shaped by the social contexts in which we find ourselves. The historical moment of the early twenty-first century in the United States is one of continued gender, racial ethnic, and social class inequality. Yet, it is also a moment of increased options and possibilities for diverse ways of creating and living in families. These articles provide a window into that contemporary world. 